\title{
High Prevalence of Diabetes Among Indo-Guyanese Adults, Schenectady, New York
}

\begin{abstract}
Akiko S. Hosler, PhD; David S. Pratt, MD, MPH; Kathryn A. Sen, RN; Erin M. Buckenmeyer, MPH; Alexander Simao Jr, MPH; Ephraim E. Back, MD, MPH; Sanghamitra Savadatti, MPH; Jennifer L. Kahn, MPH, CHES; Glynnis S. Hunt, MS

Suggested citation for this article: Hosler AS, Pratt DS, Sen KA, Buckenmeyer EM, Simao A Jr, Back EE, et al. High Prevalence of Diabetes Among Indo-Guyanese Adults, Schenectady, New York. Prev Chronic Dis 2013;10:120211. DOI: http://dx.doi.org/10.5888/pcd10.120211 图.
\end{abstract}

PEER REVIEWED

\section{Abstract}

\section{Introduction}

The Indo-Guyanese population is the largest immigrant minority population in Schenectady, New York. A clinic-based study in Schenectady and surveillance reports from Guyana found high diabetes prevalence and mortality among Guyanese of Indian descent. No community-based study has focused on diabetes among Indo-Guyanese immigrants in the United States. We sought information on the prevalence of diabetes and its complications in Indo-Guyanese adults in Schenectady and compared it with the prevalence among non-Hispanic white adults in Schenectady.

\section{Methods}

We administered a cross-sectional health survey at community venues in Schenectady in 2011. We identified diagnosed diabetes and its complications through self-reports by using a reliability-tested questionnaire. The final data set included 313 Indo-Guyanese and 327 non-Hispanic white adults aged 18 years or older. We compared the prevalence of diagnosed diabetes and diabetes complications between Indo-Guyanese and non-Hispanic whites.

\section{Results}

Most Indo-Guyanese participants were born in Guyana, whereas most non-Hispanic whites were born in the United States. The crude prevalence of diagnosed diabetes among Indo-Guyanese participants and non-Hispanic whites was $30.3 \%$ and $16.1 \%$, respectively. The age-standardized prevalence was $28.7 \%$ among Indo-Guyanese participants, significantly higher than that among non-Hispanic whites $(14.5 \%, P<.001)$. Indo-Guyanese participants who had diabetes had a lower body mass index and were more likely to report poor or fair general health and eye or vision complications than non-Hispanic whites who had diabetes.

\section{Conclusion}

Our study confirms the higher prevalence of diabetes in Indo-Guyanese adults in Schenectady. The higher prevalence of complications suggests poor control of diabetes. Excess burden of diabetes in this population calls for further research and public health action.

\section{Introduction}

The Indo-Guyanese population is one of the fastest growing immigrant groups in North America (1) and the largest immigrant minority population in Schenectady, New York. The city is home to an estimated 8,0oo Indo-Guyanese people (or $12 \%$ of the total population) and one of the most visible Indo-Guyanese communities in the United States. Most Indo-Guyanese trace their ancestry to the mid-180os, when (East) Indian indentured servants were brought to Guyana, an English-speaking, continental West Indian country formerly known as British Guiana (1). Having very little intermarriage, this group is phenotypically and genotypically Indian and preserves its distinctive culture.

The Indo-Guyanese community is disproportionately affected by diabetes. A clinic-based study conducted in an academic hospital in Schenectady during 2004-2006 found an age-standardized prevalence of diabetes among Indo- 
Guyanese patients of 31.6\%, twice that of whites and 65\% higher than that of African Americans (2). Likewise, surveillance reports from Guyana indicated significantly higher diabetes prevalence and mortality among Guyanese of Indian descent (3-5), and New York City-based studies reported similar findings $(6,7)$. The existing studies of IndoGuyanese in the United States, however, are not population-based or are limited by secondary analyses of administrative data. No community-based study has focused on diabetes among Indo-Guyanese immigrants in the United States. The objective of this study was to ascertain the prevalence of diabetes, diabetes complications, and related health indicators in Indo-Guyanese adults in Schenectady and compare them with the same factors among non -Hispanic whites, the majority population in the community.

\section{Methods}

We conducted a cross-sectional health survey from February to November 2011 in Schenectady, New York. Schenectady residents aged 18 years or older who understood and signed consent forms were eligible to participate in the survey. Power analysis showed that at least 280 Indo-Guyanese and 280 non-Indo-Guyanese respondents were needed to achieve a power of $90 \%$ for the expected prevalence difference. Because the US population census does not recognize Indo-Guyanese as a racial/ethnic category, and the Indo-Guyanese do not live in enclaves, we used convenience sampling for this study. We recruited respondents at 36 community locations and events: faith-based organizations $(n=8)$, community festivals $(n=6)$, worksites $(n=5)$, community meetings $(n=4)$, retailers $(n=4)$, schools $(n=3)$, health care facilities $(n=3)$, county government sites $(n=2)$, and a sporting event. Eleven of these locations and events catered primarily to the Indo-Guyanese community. A few Indo-Guyanese respondents were also recruited through referrals from community members and door-to-door visits. We monitored the age-sex distribution of Indo-Guyanese and non-Indo-Guyanese respondents and adjusted recruitment strategies to ensure that the sample had a similar age-sex distribution of the city's adult population.

We developed a paper-and-pencil, self-administered, 42-item questionnaire in English. The questionnaire was structured at a 6th-grade reading level and used standardized questions from the Behavioral Risk Factor Surveillance System (8) and previously published studies $(9,10)$. Test-retest reliability, assessed with a convenience sample of Indo -Guyanese and non-Indo-Guyanese $(n=12)$ found perfect agreement in 9 key variables, including age, sex, diagnosis of diabetes, and family history of diabetes, and excellent agreement (prevalence-adjusted bias-adjusted $\kappa \geq 80.0$ ) in all other health-related variables. Trained research team members and trained members of Schenectady County's Medical Reserve Corps and Women, Infants, and Children (WIC) staff provided assistance in completing the questionnaire, if requested by the respondent. The institutional review board of Ellis Hospital, Schenectady, reviewed and approved this study.

All information in this study was based on self-report. We identified respondents as Indo-Guyanese if they selfidentified as Guyanese, indicated they were born in Guyana, or both, and they indicated their race as (East) Indian or Asian or had an Indian surname. Diagnosed diabetes was assessed by the question, "Has a health professional ever told you that you have diabetes?" We calculated body mass index (BMI) by using reported height without shoes (in inches) and weight (in pounds). Family history of diabetes was evaluated with the question, "Do/did you have a blood relative in your immediate family (mother, father, sisters or brothers) who has/had diabetes?” We assessed diabetes complications and comorbidities by lifetime diagnosis; diabetes-related hospitalization was assessed for the previous year.

Of 811 survey participants, 792 aged 18 or older remained in the data set after 12 duplicate responses and 7 ineligible respondents were removed. The 7 ineligible respondents had a Schenectady zip code but lived outside the city's administrative boundaries. We found no significant differences in demographic characteristics between the removed and the remaining respondents. We computed sampling weights for the analysis. Indo-Guyanese and non-IndoGuyanese samples were divided into 8 age-sex groups. We calculated an expected sample size for each cell by multiplying the total sample size by the fraction of the city's age-sex distribution obtained from the 2010 census. The sampling weight was obtained by dividing the expected sample size by the actual sample size. We conducted univariate analysis, and data were weighted to reflect the population distributions in the study.

We computed prevalence of diagnosed diabetes, diabetes complications, and related health indicators for IndoGuyanese $(\mathrm{n}=313)$ and non-Hispanic whites $(\mathrm{n}=327)$ with known diabetes status. Those in other racial/ethnic groups $(n=149)$ and whose diabetes status was unknown $(n=3)$ were not included. We used the $z$ test for proportions to obtain the $P$ values for differences in prevalence. The age-standardized prevalence of diabetes was computed to enable us to compare our results with the results of the earlier clinic-based study (2). We used the direct age-standardization method, which used the 2000 US population as a standard. We used SPSS-PC version 19.0 (IBM, Inc, Chicago, Illinois) and PEPI version 4.4 (11) for the analyses. 


\section{Results}

The mean age was 44.9 years for Indo-Guyanese and 47.4 years for non-Hispanic whites (Table 1). Most (95.9\%) IndoGuyanese were born in Guyana, whereas most (97.2\%) non-Hispanic whites were born in the United States. Almost $60 \%$ of Indo-Guyanese had a high school diploma or the equivalent, and nearly half had an annual household income of less than \$20,000. Approximately 25\% of Indo-Guyanese were uninsured, compared with $6.4 \%$ of non-Hispanic whites. The mean BMI was similar in both groups.

The crude prevalence of diagnosed diabetes was 30.3\% (95\% confidence interval [CI], 25.4\%-35.6\%) for IndoGuyanese and 16.1\% (95\% CI, 12.5\%-20.5\%) for non-Hispanic whites $(P<.001)$ (Table 2). The age-standardized prevalence was $28.7 \%$ (95\% CI, 23.9\%-34.0\%) for Indo-Guyanese and 14.5\% (95\% CI, 10.9\%-18.5\%) for non-Hispanic whites $(P<.001)$, with a prevalence ratio of 2.o. Prevalence increased with age in both groups, and the prevalence ratio between the 2 groups remained relatively constant across age categories. Indo-Guyanese women had significantly higher prevalence than non-Hispanic white women (35.9\% vs $14.7 \%, P<.001)$ and Indo-Guyanese men $(35.9 \%$ vs $24.2 \%, P=.03$ ). The prevalence of diabetes was nearly 3 times as high among overweight (BMI $25.0-29.9 \mathrm{~kg} / \mathrm{m}^{2}$ ) Indo -Guyanese as among overweight non-Hispanic whites (35.9\% vs $12.8 \%, P<.001)$. Family history of diabetes was associated with higher prevalence of diabetes in both Indo-Guyanese and non-Hispanic whites.

Indo-Guyanese who had diabetes generally had a higher prevalence of diabetes-related complications, comorbidities, and hospitalizations (Table 3). In particular, Indo-Guyanese had a higher prevalence of eye or vision complications ( $46.4 \%$ vs $21.1 \%, P=.004$ ) and were more likely to report their general health status as fair or poor ( $43.6 \%$ vs $15.8 \%, P$ $=.001)$. Indo-Guyanese who had diabetes had a significantly lower BMI than non-Hispanic whites who had diabetes (28.7 vs 31.2, $P=.009$ ).

\section{Discussion}

Our study is the first community-based study to compare the prevalence of diagnosed diabetes and its complications among Indo-Guyanese adults with the prevalence among non-Hispanic whites. It confirms that diabetes disproportionately affects the Indo-Guyanese community in Schenectady as was suggested in the earlier clinic-based study (2).

This high prevalence of diabetes in people of Indian descent is not unique to Schenectady. It reflects the higher prevalence of diabetes in descendants of Indian diasporas in small islands including Fiji, Trinidad, and Guadeloupe (12 -15) as well as Indian immigrants in major cities in the United States (16-18) and Europe (19,20). These consistent observations of higher prevalences of diabetes in generations of Indian immigrants around the world warrant genetic studies. Researchers have reported a constellation of metabolic abnormalities and cardiovascular risks commonly found in populations from the Indian subcontinent, characterized by atherogenic dyslipidemia, glucose intolerance, thrombotic tendency, subclinical inflammation, and endothelial dysfunction (21). One significant finding of our study is that Indo-Guyanese with diabetes have a lower average BMI than non-Hispanic whites with diabetes. In general, Indian populations have higher levels of abdominal visceral fat regardless of their overall adiposity. This "metabolically obese" phenotype (eg, normal weight by conventional BMI standards but increased abdominal adiposity) has been associated with increased risk of insulin resistance and diabetes in Indian populations $(17,22)$. This postulation needs to be studied further in the Indo-Guyanese population.

In addition to genetic predisposition, differences in educational attainment, household income, and insurance status between Indo-Guyanese and non-Hispanic whites suggest differential access to measures that prevent diabetes. Socioeconomic status (SES) is inversely associated with risks of type 2 diabetes, and this association is independent of the income levels of countries (23). Furthermore, rapid transitions in dietary behavior and physical activity status that follow international migration can contribute to the increased diabetes risks in Indo-Guyanese (20,21). Further research is needed to understand the roles of SES (as a confounder or an effect modifier) and lifestyle change in the development of diabetes in this population.

Higher prevalence of eye or vision complications and less favorable ratings of general health suggest poor control of diabetes in Indo-Guyanese. Our preliminary assessment of the Indo-Guyanese community indicated that lack of health insurance coverage, lack of a regular medical care provider, and low health literacy are likely barriers to diabetes control (D.S. Pratt, K.A. Sen, A. Simao Jr, G.S. Hunt, Schenectady County Public Health Services, unpublished data, September 1, 2012). Indo-Guyanese cultural beliefs, attitudes, and collective behavior toward diabetes and its care, as well as social support structure, can also determine diabetes control, but very little research has been conducted to provide sufficient information.

There are limitations in this study. Assessment of diabetes prevalence based on self-reported diagnosis underestimates the true extent of diabetes. The Centers for Disease Control and Prevention reports that approximately $27 \%$ of all diabetes cases in the United States are undiagnosed, and 35\% of the US population has prediabetes, a major risk factor 
for type 2 diabetes (24). Undiagnosed diabetes may be more prevalent in Indo-Guyanese than in non-Hispanic whites because Indo-Guyanese have less access to health care. Type of diabetes was not assessed in this study. Almost all cases of diabetes in Indo-Guyanese are believed to be type 2, according to literature and the earlier clinical study (2,20,25). BMI was assessed by self-reported height and weight, which may have resulted in underestimation of BMI. The prevalence of diabetes complications was not adjusted for the duration of diabetes, treatment regimen, or medical care use. We did not collect a measure for abdominal adiposity because of the difficulty of obtaining such information through an interview survey.

There are also intrinsic limitations of convenience sampling, including inability to generalize its findings. It is likely that people affected by diabetes were more willing to participate in the survey, resulting in volunteer bias. High socioeconomic status of the non-Hispanic white sample could be an indication of selection bias as well. We do not know how age, sex, and socioeconomic characteristics differ between Indo-Guyanese and non-Hispanic white populations because of the lack of relevant census information. Given that random-digit-dialing telephone methods also have intrinsic limitations for reaching low SES immigrant minority groups like Indo-Guyanese (26), we believe our sampling strategy was appropriate for our study objective.

This community-based study found nearly twice the overall prevalence of diagnosed diabetes in Indo-Guyanese adults than in non-Hispanic white adults. Indo-Guyanese also had signs of poor diabetes control. The disproportionate burden of diabetes in the Indo-Guyanese population could be larger if undiagnosed cases and prediabetes are taken into account. Although the Indo-Guyanese population is most likely genetically predisposed to develop diabetes, low SES, immigration experience, and cultural factors are also likely to be associated with the higher burden of diabetes. Further research to understand the complex mechanism of diabetes disparities is strongly needed. Medical professionals should be aware that Indo-Guyanese adults can develop type 2 diabetes without becoming obese. Diabetes screening criteria specific to South Asian populations may be more appropriate for assessing diabetes risks in the Indo-Guyanese population (27).

\section{Acknowledgments}

This study was supported by the Centers for Disease Control and Prevention Racial and Ethnic Approaches to Community Health for Communities Organized to Respond and Evaluate (REACH CORE) funding (U58DPoo298302). We thank Joanne Cocozzoli and Stephanie Scuderi of the Schenectady County Public Health Services, and Sarah Murtaza, Association of Schools of Public Health Fellow, and Leah Connor of the University at Albany for their support of this project. We thank the West Indian/Indo-Guyanese residents in Schenectady for their cooperation and patience in this effort. The authors have no relevant conflicts of interest to disclose.

\section{Author Information}

Corresponding Author: Akiko S. Hosler, PhD, Department of Epidemiology and Biostatistics, University at Albany School of Public Health, One University Place, Rensselaer, NY 12144-3456. Telephone: 518-402-1561. E-mail: ahosler@albany.edu.

Author Affiliations: David S. Pratt, Kathryn A. Sen, Alexander Simao Jr, Glynnis S. Hunt, Schenectady County Public Health Services, Schenectady, New York; Erin M. Buckenmeyer, Sanghamitra Savadatti, University at Albany School of Public Health, Rensselaer, New York; Ephraim E. Back, Ellis Medicine, Schenectady, New York; Jennifer L. Kahn, Cornell Cooperative Extension of Schenectady County, Schenectady, New York.

\section{References}

1. Orozco M. Remitting back home and supporting the homeland: the Guyanese community in the U.S. Washington (DC): US Agency for International Development; 2003.

2. Back EE, Bachwani AS, Strogatz DS, Sherman ZM. Profile of diabetes mellitus among immigrants from Guyana: epidemiology and implications for community action. Ethn Dis 2012;22(4):473-8. PubMed

3. Statistical Unit of the Guyana Ministry of Health. Statistical bulletin 2008. Georgetown (GY): Guyana Ministry of Health; 2008.

4. Health Systems 20/20 and the Guyana Ministry of Health. Guyana health system assessment 2010. Bethesda (MD): Abt Associates, Inc; 2011.

5. Wilson LC, Wilson CM, Johnson BM. Race and health in Guyana: an empirical assessment from survey data. Caribb Stud 2010;38(1):37-58. CrossRef 图 PubMed 图

6. Silbiger JJ, Stein R, Trost B, Shaffer J, Kim JH, Cohen P, et al. Coronary angiographic findings and conventional coronary artery disease risk factors of Indo-Guyanese immigrants with stable angina pectoris and acute coronary syndromes. Ethn Dis 2012;22(1):12-4. PubMed 图 
7. Kim M, Van Wye G, Kerker B, Thorpe L, Frieden T. The health of immigrants in New York City. New York (NY): New York City Department of Health and Mental Hygiene; 2006.

8. Centers for Disease Control and Prevention. Behavioral Risk Factor Surveillance System survey questionnaire. Atlanta (GA): US Department of Health and Human Services, Centers for Disease Control and Prevention; 2011.

9. Hosler AS, Melnik TA. Prevalence of diagnosed diabetes and related risk factors: Japanese adults in Westchester County, New York. Am J Public Health 2003;93(8):1279-81. CrossRef $\mathbf{w}^{\circ}$ PubMed 鹿

10. Melnik TA, Hosler AS, Sekhobo JP, Duffy TP, Tierney EF, Engelgau MM, et al. Diabetes prevalence among Puerto Rican adults in New York City, NY, 2000. Am J Public Health 2004;94(3):434-7. CrossRef 图 PubMed 豦

11. Abramson JH, Gahlinger PM. Computer programs for epidemiologists (PEPI) v.4.o. Salt Lake City (UT): Sagebrush Press; 2001.

12. Hoskins PL, Handelsman DJ, Hannelly T, Silink M, Yue DK, Turtle JR. Diabetes in the Melanesian and Indian peoples of Fiji: a study of risk factors. Diabetes Res Clin Pract 1987;3(5):269-76. CrossRef $\mathbf{s}^{*}$ PubMed

13. Miller GJ, Beckles GL, Maude GH, Carson DC, Alexis SD, Price SG, et al. Ethnicity and other characteristics predictive of coronary heart disease in a developing community: principal results of the St James Survey, Trinidad. Int J Epidemiol 1989;18(4):808-17. CrossRef 图 PubMed 图

14. Costagliola D, Delaunay C, Moutet JP, Kankambega P, Demeulemeester R, Donnet JP, et al. The prevalence of diabetes mellitus in the adult population of Guadeloupe as estimated by history or fasting hyperglycemia. Diabetes Res Clin Pract 1991;12(3):209-16. CrossRef 店 PubMed 通

15. Miller GJ, Maude GH, Beckles GL. Incidence of hypertension and non-insulin dependent diabetes mellitus and associated risk factors in a rapidly developing Caribbean community: the St James survey, Trinidad. J Epidemiol Community Health 1996;50(5):497-504. CrossRef

16. Venkataraman R, Nanda NC, Baweja G, Parikh N, Bhatia V. Prevalence of diabetes mellitus and related conditions

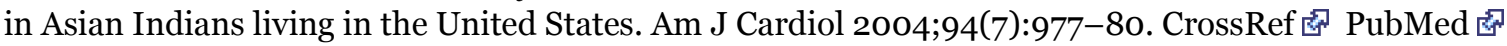

17. Kanaya AM, Wassel CL, Mathur D, Stewart A, Herrington D, Budoff MJ, et al. Prevalence and correlates of diabetes in South Asian Indians in the United States: findings from the Metabolic Syndrome and Atherosclerosis in South Asians Living in America and the Multi-Ethnic Study of Atherosclerosis. Metab Syndr Relat Disord 2010;8(2):157-64. CrossRef 图 PubMed 图

18. Gupta LS, Wu CC, Young S, Perlman SE. Prevalence of diabetes in New York City, 2002-2008: comparing foreign -born South Asians and other Asians with U.S.-born whites, blacks, and Hispanics. Diabetes Care 2011;34(8):1791 -3. CrossRef 豦 PubMed 通

19. Wandel M, Raberg M, Kumar B, Holmboe-Ottesen G. Changes in food habits after migration among South Asians settled in Oslo: the effect of demographic, socio-economic and integration factors. Appetite 2008;50(2-3):376-85. CrossRef 㐘 PubMed 因

20. Gholap N, Davies M, Patel K, Sattar N, Khunti K. Type 2 diabetes and cardiovascular disease in South Asians. Prim Care Diabetes 2011;5(1):45-56. CrossRef 處 PubMed 通

21. Misra A, Khurana L. The metabolic syndrome in South Asians: epidemiology, determinants, and prevention.

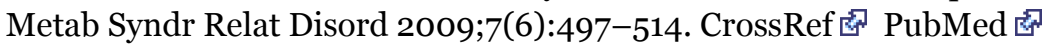

22. Ruderman N, Chisholm D, Pi-Sunyer X, Schneider S. The metabolically obese, normal-weight individual revisited. Diabetes 1998;47(5):699-713. CrossRef 迢 PubMed 通

23. Agardh E, Allebeck P, Hallqvist J, Moradi T, Sidorchuk A. Type 2 diabetes incidence and socio-economic position: a systematic review and meta-analysis. Int $J$ Epidemiol 2011;40(3):804-18. CrossRef 因 PubMed 远

24. Centers for Disease Control and Prevention. National diabetes fact sheet: national estimates and general information on diabetes and prediabetes in the United States, 2011. Atlanta (GA): US Department of Health and Human Services, Centers for Disease Control and Prevention; 2011.

25. Abate N, Chandalia M. Ethnicity, type 2 diabetes and migrant Asian Indians. Indian J Med Res 2007;125(3):2518. PubMed 祭

26. Blumberg SJ, Luke JV. Reevaluating the need for concern regarding noncoverage bias in landline surveys. Am J Public Health 2009;99(10):1806-10. CrossRef 图 PubMed 處

27. Mohan V, Deepa R, Deepa M, Somannavar S, Datta M. A simplified Indian Diabetes Risk Score for screening for undiagnosed diabetic subjects. J Assoc Physicians India 2005;53:759-63. PubMed 虑 


\section{Tables}

Table 1. Weighteda Characteristics of Indo-Guyanese and Non-Hispanic White Respondents, Schenectady, New York, 2011

\begin{tabular}{|c|c|c|}
\hline Characteristic & Indo-Guyanese $(n=313)$ & Non-Hispanic White $(n=327)$ \\
\hline Age, y, mean (SD) & $44.9(16.7)$ & $47.4(17.7$ \\
\hline Female, \% & 52.2 & 51.2 \\
\hline \multicolumn{3}{|l|}{ Place of birth, \% } \\
\hline United States & 4.1 & 97.2 \\
\hline Guyana & 95.9 & c \\
\hline Other & 0 & 2.8 \\
\hline \multicolumn{3}{|l|}{ Educational attainment, \% } \\
\hline$<$ High school graduate & 31.3 & 2.6 \\
\hline High school graduate or equivalent & 58.7 & 28.6 \\
\hline$\geq$ Some college & 10.0 & 68.8 \\
\hline \multicolumn{3}{|l|}{ Annual household income, \% } \\
\hline$<\$ 20,000$ & 49.1 & 12.5 \\
\hline$\$ 20,000-\$ 49,999$ & 40.1 & 22.5 \\
\hline$\geq \$ 50,000$ & 10.8 & 64.2 \\
\hline BMI, mean (SD), kg/m² & $27.1(4.8)$ & $27.5(5.8$ \\
\hline Family history of diabetes, \% & 57.1 & 43.4 \\
\hline \multicolumn{3}{|l|}{ Health insurance coverage, $\%$} \\
\hline Private insurance & 38.4 & 68.5 \\
\hline Public insurance & 35.5 & 25.1 \\
\hline Uninsured & 26.1 & 6.2 \\
\hline
\end{tabular}

Abbreviation: SD, standard deviation; BMI, body mass index.

a Data were weighted to reflect the population distributions in the study.

Table 2. Weighteda Prevalence of Self-Reported Diagnosed Diabetes in IndoGuyanese and Non-Hispanic White Adults, Schenectady, New York, 2011 ${ }^{\mathrm{b}}$

\begin{tabular}{|c|c|c|c|c|c|c|}
\hline \multirow[b]{2}{*}{ Characteristic } & \multicolumn{2}{|c|}{ Indo-Guyanese } & \multicolumn{2}{|c|}{$\begin{array}{l}\text { Non-Hispanic } \\
\text { White }\end{array}$} & \multirow{2}{*}{$\begin{array}{c}P \text { Value for Prevalence } \\
\text { Differencec }\end{array}$} & \multirow{2}{*}{$\begin{array}{l}\text { Prevalence } \\
\text { Ratio }\end{array}$} \\
\hline & $\mathbf{n}$ & $\%(95 \% \mathrm{CI})$ & $\mathbf{n}$ & $\%(95 \% \mathrm{CI})$ & & \\
\hline Crude & 313 & $\begin{array}{r}30.3(25.4- \\
35.6)\end{array}$ & 327 & $\begin{array}{r}16.1(12.5- \\
20.5)\end{array}$ & $<.001$ & 1.9 \\
\hline \multicolumn{7}{|l|}{ Age group, y } \\
\hline $18-29$ & 72 & $3.2(0.5-8.9)$ & 58 & $1.7(0.1-8.2)$ & .99 & 1.9 \\
\hline $30-44$ & 81 & $\begin{array}{r}12.9(6.4- \\
20.9)\end{array}$ & 85 & $7.7(3.7-15.6)$ & .40 & 1.7 \\
\hline $45-59$ & 87 & $\begin{array}{r}42.9(32.5- \\
53.1)\end{array}$ & 98 & $22.4\left(\begin{array}{r}15.0- \\
31.5)\end{array}\right.$ & .005 & 1.9 \\
\hline
\end{tabular}




\begin{tabular}{|c|c|c|c|c|c|c|}
\hline \multirow[b]{2}{*}{ Characteristic } & \multicolumn{2}{|c|}{ Indo-Guyanese } & \multicolumn{2}{|c|}{$\begin{array}{c}\text { Non-Hispanic } \\
\text { White }\end{array}$} & \multirow{2}{*}{$\begin{array}{c}P \text { Value for Prevalence } \\
\text { Differencec }\end{array}$} & \multirow{2}{*}{$\begin{array}{l}\text { Prevalence } \\
\text { Ratio }\end{array}$} \\
\hline & $\mathbf{n}$ & $\%(95 \% \mathrm{CI})$ & $\mathbf{n}$ & $\%(95 \% \mathrm{CI})$ & & \\
\hline$\geq 60$ & 73 & $\begin{array}{r}61.2(50.1- \\
72.2)\end{array}$ & 85 & $\begin{array}{r}28.3(19.4- \\
38.5)\end{array}$ & $<.001$ & 2.2 \\
\hline \multicolumn{7}{|l|}{ Sex } \\
\hline Male & 150 & $\begin{array}{r}24.2(17.7- \\
31.3)\end{array}$ & 159 & $\begin{array}{r}16.6(11.2- \\
22.7)\end{array}$ & .13 & 1.5 \\
\hline Female & 163 & $\begin{array}{r}35.9(29.1- \\
43.8) \\
\end{array}$ & 168 & $\begin{array}{r}14.7(10.6- \\
19.5) \\
\end{array}$ & $<.001$ & 2.4 \\
\hline \multicolumn{7}{|l|}{$B M I, \mathbf{k g} / \mathrm{m}^{2}$} \\
\hline$<25.0$ & 97 & $\begin{array}{r}15.5(9.3- \\
23.7)\end{array}$ & 115 & $9.7(5.1-16.0)$ & .29 & 1.6 \\
\hline $25.0-29.9$ & 127 & $\begin{array}{r}35.9(28.2- \\
44.9)\end{array}$ & 118 & $\begin{array}{r}12.8(7.6- \\
19.7) \\
\end{array}$ & $<.001$ & 2.8 \\
\hline$\geq 30.0$ & 71 & $\begin{array}{r}37.5(27.3- \\
49.7)\end{array}$ & 84 & $\begin{array}{r}30.8(21.8- \\
41.4)\end{array}$ & .48 & 1.2 \\
\hline \multicolumn{7}{|c|}{ Family history of diabetes } \\
\hline With family history & 178 & $\begin{array}{r}38.9(31.8- \\
46.1)\end{array}$ & 141 & $\begin{array}{r}24.8(18.2- \\
32.4)\end{array}$ & .01 & 1.6 \\
\hline No family history & 129 & $\begin{array}{r}18.3(12.6- \\
26.0)\end{array}$ & 182 & $8.1(4.9-12.9)$ & .01 & 2.3 \\
\hline $\begin{array}{l}\text { Age- } \\
\text { standardized }\end{array}$ & 313 & $\begin{array}{r}28.7(23.9- \\
34.0)\end{array}$ & 327 & $\begin{array}{r}14.5(10.9- \\
18.5)\end{array}$ & $<.001$ & 2.0 \\
\hline
\end{tabular}

Abbreviation: CI, confidence interval; BMI, body mass index.

a Data were weighted to reflect the population distributions in the study.

b Numbers may not equal the total because of missing data.

${ }^{\mathrm{c}} z$ test for proportions was used to obtain $P$ values.

Table 3. Weighteda Prevalence of Complications and Health Indicators Among Indo-Guyanese and Non-Hispanic Whites With Diabetes, Schenectady, New York, 2011

\begin{tabular}{|c|c|c|c|c|c|}
\hline \multirow[b]{2}{*}{ Characteristic } & \multicolumn{2}{|c|}{ Indo-Guyanese } & \multicolumn{2}{|c|}{$\begin{array}{l}\text { Non-Hispanic } \\
\text { White }\end{array}$} & \multirow{2}{*}{$\begin{array}{c}P \text { Value for Prevalence } \\
\text { Difference }^{\mathbf{b}}\end{array}$} \\
\hline & n & Value & $\mathbf{n}$ & Value & \\
\hline Age, $y$, mean (SD) & 95 & $57.6(12.4)$ & 52 & $57.9(14.0)$ & .89 \\
\hline BMI, kg/m², mean (SD) & 87 & $28.7(4.3)$ & 52 & $31.2(6.9)$ & .009 \\
\hline Nerve complication, \% (95\% CI) & 94 & $\begin{array}{r}48.8(38.9- \\
59.0) \\
\end{array}$ & 52 & $\begin{array}{r}36.2(24.3- \\
50.2) \\
\end{array}$ & .20 \\
\hline $\begin{array}{l}\text { Eye or vision complication, \% (95\% } \\
\text { CI) }\end{array}$ & 93 & $\begin{array}{r}46.4(36.3- \\
56.4) \\
\end{array}$ & 52 & $\begin{array}{r}21.1(11.7- \\
33.8) \\
\end{array}$ & .004 \\
\hline Kidney complication, \% (95\% CI) & 90 & $\begin{array}{r}23.7(15.5- \\
32.9) \\
\end{array}$ & 50 & $15.8(7.7-28.1)$ & .38 \\
\hline Diabetes hospitalization, \% $(95 \% \mathrm{CI})$ & 93 & $13.6(8.0-22.2)$ & 52 & $9.8(3.6-20.0)$ & .69 \\
\hline High blood pressure, \% (95\% CI) & 95 & $\begin{array}{r}68.1(58.6- \\
77.2)\end{array}$ & 53 & $\begin{array}{r}59.1(44.9- \\
71.1)\end{array}$ & .36 \\
\hline
\end{tabular}




\begin{tabular}{|c|c|c|c|c|c|}
\hline \multirow[b]{2}{*}{ Characteristic } & \multicolumn{2}{|c|}{ Indo-Guyanese } & \multicolumn{2}{|r|}{$\begin{array}{l}\text { Non-Hispanic } \\
\text { White }\end{array}$} & \multirow{2}{*}{$\begin{array}{c}\text { P Value for Prevalence } \\
\text { Differenceb }\end{array}$} \\
\hline & $\mathbf{n}$ & Value & $\mathbf{n}$ & Value & \\
\hline High blood cholesterol, \% (95\% CI) & 95 & $\begin{array}{r}61.7(52.1- \\
71.4)\end{array}$ & 53 & $\begin{array}{r}67.8(54.5- \\
79.4)\end{array}$ & .57 \\
\hline Heart disease, $\%(95 \% \mathrm{CI})$ & 95 & $\begin{array}{r}23.9(16.4- \\
33.6)\end{array}$ & 53 & $\begin{array}{r}20.1(11.4- \\
32.2)\end{array}$ & .75 \\
\hline $\begin{array}{l}\text { Fair or poor general health, } \%(95 \% \\
\text { CI) }\end{array}$ & 95 & $\begin{array}{r}43.6(33.5- \\
53.3)\end{array}$ & 53 & $15.8(7.3-26.7)$ & .001 \\
\hline
\end{tabular}

Abbreviation: SD, standard deviation; BMI, body mass index; CI, confidence interval.

a Data were weighted to reflect the population distributions in the study.

$\mathrm{b} z$ test for proportions was used to obtain $P$ values.

The opinions expressed by authors contributing to this journal do not necessarily reflect the opinions of the U.S. Department of Health and Human Services, the Public Health Service, the Centers for Disease Control and Prevention, or the authors' affiliated institutions.

The RIS file format is a text file containing bibliographic citations. These files are best suited for import into bibliographic management applications such as EndNote $\mathbf{*}$, Reference Manager $\mathbf{3}$, and ProCite $\mathbf{3}$. A free trial download is available at each application's web site.

For Questions About This Article Contact pcdeditor@cdc.gov

Page last reviewed: March 28, 2013

Page last updated: March 28, 2013

Content source: National Center for Chronic Disease Prevention and Health Promotion

Centers for Disease Control and Prevention 1600 Clifton Rd. Atlanta, GA 30333, USA

80o-CDC-INFO (800-232-4636) TTY: (888) 232-6348 - Contact CDC-INFO 